\begin{tabular}{l|l|l|l}
$\begin{array}{c}\text { Case Reports in } \\
\text { Demiliatology }\end{array}$ & $\begin{array}{l}\text { Case Rep Dermatol 2011;3:8-12 } \\
\text { DOI: } 10.1159 / 000324190\end{array}$ & $\begin{array}{l}\text { Published online: } \\
\text { January 22, 2011 }\end{array}$ & $\begin{array}{l}\text { I 2011 S. Karger AG, Basel } \\
\text { ISSN 1662-6567 } \\
\text { www.karger.com/cde }\end{array}$ \\
\hline
\end{tabular}

This is an Open Access article licensed under the terms of the Creative Commons AttributionNonCommercial-NoDerivs 3.0 License (www.karger.com/OA-license), applicable to the online version of the article only. Distribution for non-commercial purposes only.

\title{
Linear Psoriasis - A Case Report
}

\author{
$\begin{array}{llll}\text { Ana Brinca F. Santiago D. Serra P. Andrade R. Vieira } & \text { D. }\end{array}$
}

A. Figueiredo

Dermatology Department, Coimbra University Hospitals, Coimbra, Portugal

\section{Key Words}

Blaschko lines · ILVEN · Psoriasis

\begin{abstract}
A 56-year-old woman presented with a 3-month history of erythematous plaques covered by scales and limited to the right side of her body. The plaques were arranged along Blaschko's lines with a marked mid-line cutoff. The histopathologic analysis of a skin biopsy in conjunction with the anamnesis allowed the diagnosis of linear psoriasis. Our patient showed a good clinical response to antipsoriatic treatment.
\end{abstract}

\section{Introduction}

Linear psoriasis is a rare form of psoriasis, characterized by a linear distribution of the psoriatic lesions along Blaschko's lines. The main differential diagnosis is inflammatory linear verrucous epidermal nevus (ILVEN). The pathogenesis of linear psoriasis is not clear, but it could be explained by the well-established concept of genetic mosaicism.

\section{Case Report and Methods}

A 56-year-old previously healthy woman presented with a 3-month history of multiple confluent erythematous papules and plaques covered by scales. The papules and plaques had well-defined and sharply demarcated boundaries, ranged from 3 to $10 \mathrm{~mm}$ in diameter, were limited to the right side of her body and were arranged along Blaschko's lines with a marked mid-line cutoff. The lesions were first noticed in the right scapular region and progressively extended within a few weeks to the lateral aspect of the right superior limb, the right side of the trunk, the abdomen and the anterior aspect of the inferior limb, especially pronounced in the proximal third of the thigh and the knee (fig. 1). In the abdominal region, they appeared as transverse ' $S$ '-shaped lines (fig. 2). The lesions were moderately pruriginous. The patient denied any episodes of infection preceding the dermatosis. No psoriasis-form nail or scalp lesions were observed, and there was no personal or family history of psoriasis. The histopathologic analysis of a skin biopsy revealed orthokeratosis, parakeratosis and spongiosis-form Munro's microabscesses, in association with a regular elongation of rete ridges, suprapapillary thinning, and an absence of granular cell layers (ig. 3 ). 


\begin{tabular}{c|l|l|l}
$\begin{array}{c}\text { Case Reports in } \\
\text { Demillatology }\end{array}$ & $\begin{array}{l}\text { Case Rep Dermatol 2011;3:8-12 } \\
\text { DOI: } 10.1159 / 000324190\end{array}$ & $\begin{array}{l}\text { Published online: } \\
\text { January 22, 2011 }\end{array}$ & $\begin{array}{l}\text { O 2011 S. Karger AG, Basel } \\
\text { ISSN 1662-6567 } \\
\text { www.karger.com/cde }\end{array}$ \\
\hline
\end{tabular}

\section{Results}

The diagnosis of linear psoriasis was therefore established. A slight improvement was noticed after 1 month of combined treatment with betamethasone valerate and calcipotriol ointment. After complete laboratory exams including blood cell count, renal, hepatic and lipid panels, HBV and HCV serologies, and a chest radiograph, the patient was started on methotrexate $10 \mathrm{mg}$ weekly with excellent response. In the 26th week of treatment, as only residual lesions persisted, the methotrexate dose was reduced to $7.5 \mathrm{mg}$ weekly and maintained until the present time (cumulative dose of $465 \mathrm{mg}$ ) with no clinical relapse.

\section{Discussion}

Linear psoriasis is a rare form of psoriasis which was first described in 1951. There are few cases reported in the literature [1-3], and therefore there is no estimated prevalence. Also because of its clinical and histological similarity to ILVEN, some cases are probably not reported, contributing to the underdiagnosis.

The disease is characterized by psoriatic lesions distributed along Blaschko's lines. The main differential diagnosis is ILVEN, and the distinction between the two entities has been discussed in the literature [4-6]. Saraswat et al. [7] described the clinical differences between the two entities. A late onset of asymptomatic to slightly itchy lesions with a possible involvement of scalp and nails and a favorable response to antipsoriatic treatment favors the diagnosis of linear psoriasis $[8,9]$. In contrast, ILVEN lesions usually occur in the first months of life, are slowly progressive, very pruritic and highly refractory to antipsoriatic therapy. As for the histological features, ILVEN classically demonstrates hypergranulosis and parakeratosis alternating with hypogranulosis and orthokeratosis [10]. On the other hand, the classic features of psoriasis are hyperkeratosis, parakeratosis, the absence of granular cell layers, an elongation of rete ridges, suprapapillary thinning and Munro's microabscesses, which can also be seen in ILVEN. Immunohistopathologic studies may be helpful in distinguishing the two conditions, as done by Vissers et al. [4]: in ILVEN patients, the number of Ki-67-positive nuclei tended to be reduced, whereas the number of keratin-10-positive cells was increased compared with psoriasis patients. Involucrin expression, another marker, is absent in ILVEN patients but detectable in psoriasis [11]. The pathogenesis of linear psoriasis is not clear, but it could be explained by the well-established concept of genetic mosaicism [12]. 


\begin{tabular}{c|l|l|l}
$\begin{array}{c}\text { Case Reports in } \\
\text { Demillatology }\end{array}$ & $\begin{array}{l}\text { Case Rep Dermatol 2011;3:8-12 } \\
\text { DOI: } 10.1159 / 000324190\end{array}$ & $\begin{array}{l}\text { Published online: } \\
\text { January 22, 2011 }\end{array}$ & $\begin{array}{l}\text { O 2011 S. Karger AG, Basel } \\
\text { ISSN 1662-6567 } \\
\text { www.karger.com/cde }\end{array}$ \\
\hline
\end{tabular}

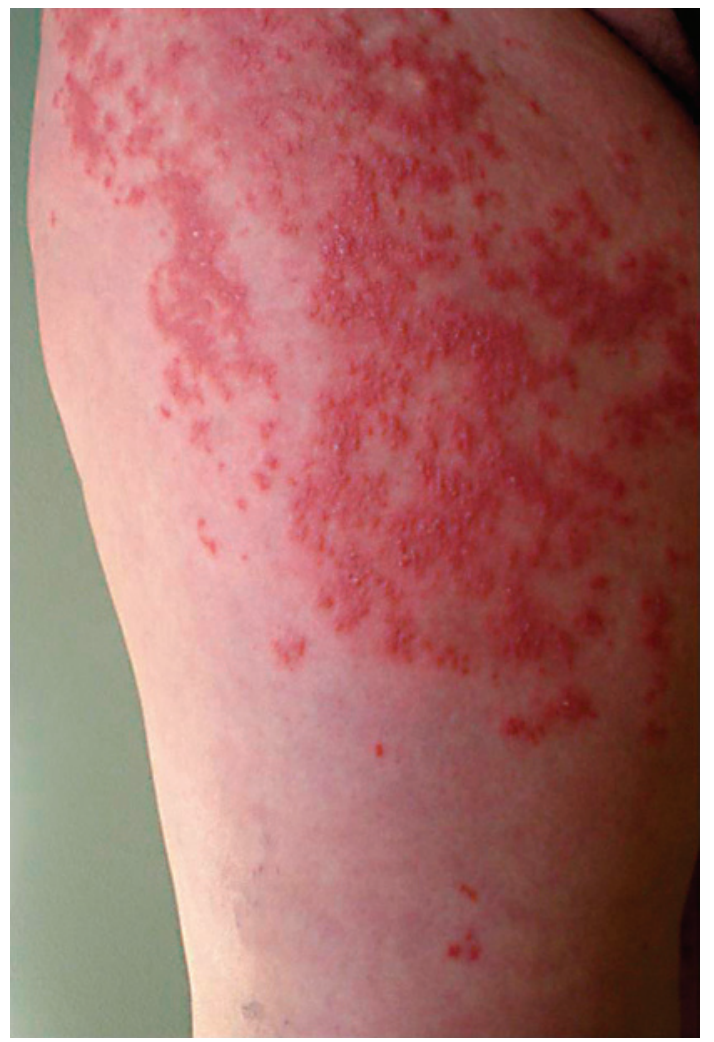

Fig. 1. Linear arrangement of psoriatic lesions on the proximal third of the thigh.

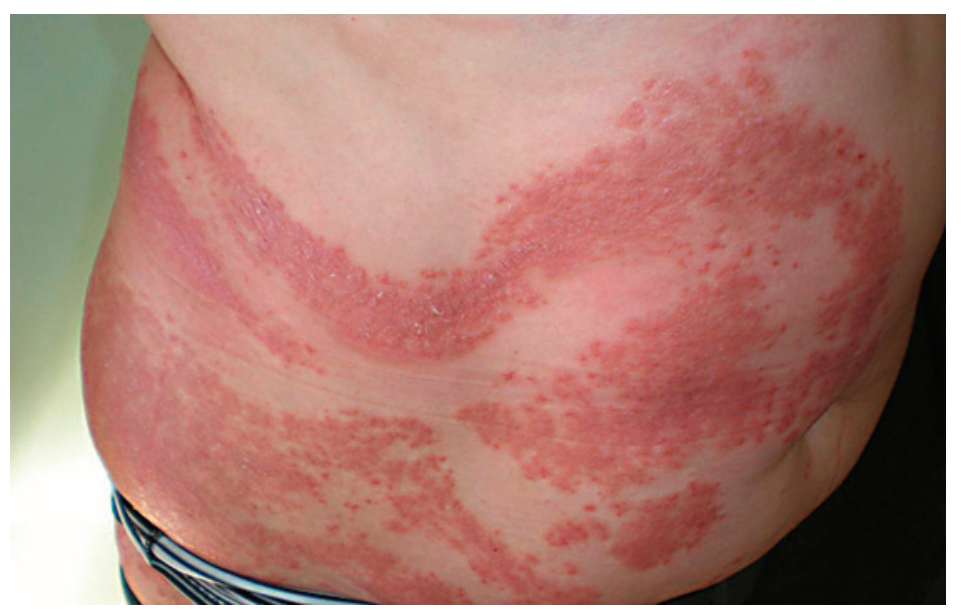

Fig. 2. Arrangement of lesions in the abdominal region: transverse ' $S$ '-shaped lines. 


\begin{tabular}{c|l|l|l} 
Case Reports in & $\begin{array}{l}\text { Case Rep Dermatol 2011;3:8-12 } \\
\text { DOI: } 10.1159 / 000324190\end{array}$ & $\begin{array}{l}\text { Published online: } \\
\text { January 22, 2011 }\end{array}$ & $\begin{array}{l}\text { O 2011 S. Karger AG, Basel } \\
\text { ISSN 1662-6567 } \\
\text { www.karger.com/cde }\end{array}$ \\
\hline
\end{tabular}

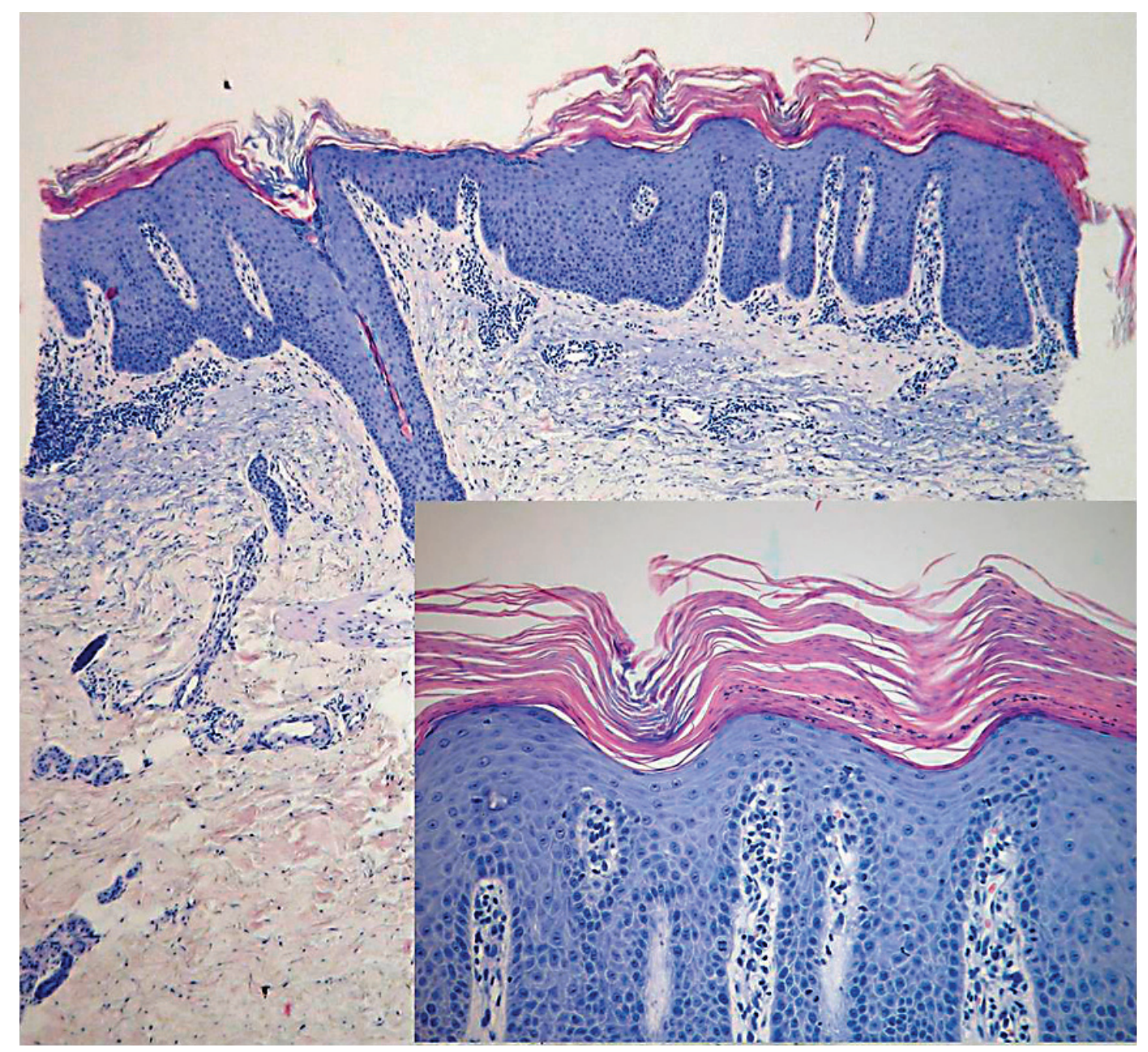

Fig. 3. Histopathologic analysis of a skin biopsy.

\section{References}

1 Chien P Jr, Rosenman K, Cheung W, Wang N, Sanchez M: Linear psoriasis. Dermatol Online J 2009;15:4.

2 Purohit S, Kanodia S, Shukla SR, Saxena VN, Meena RS, Saxena V: Linear psoriasis. Indian J Dermatol Venereol Leprol 2006;72:398.

-3 al-Fouzan AS, Hassab-el-Naby HM, Nanda A: Congenital linear psoriasis: a case report. Pediatr Dermatol 1990;7:303-306.

- Vissers WH, et al: Immunohistochemical differentiation between inflammatory linear epidermal naevus (ILVEN) and psoriasis. Eur J Dermatol 2004;14:216-220.

5 de Jong E, Rulo HF, van de Kerkhof PC: Inflammatory linear verrucous epidermal naevus (ILVEN) versus linear psoriasis. A clinical, histological and immunohistochemical study. Acta Derm Venereol 1991;71:343346.

6 Vissers WH, Muys L, Erp PE, de Jong EM, van de Kerkhof PC: Immunohistochemical differentiation between inflammatory linear verrucous epidermal nevus (ILVEN) and psoriasis. Eur J Dermatol 2004;14:216-220.

7 Saraswat A, et al: Unilateral linear psoriasis with palmoplantar, nail, and scalp involvement. Pediatr Dermatol 2004;21:70-73.

8 Ghorpade A: Linear naevoid psoriasis along lines of Blaschko. J Eur Acad Dermatol Venereol 2004;18:726-727. 
9 Lehners-Weber C, de la Brassine M, Dezfoulian B, et al: Congenital psoriasis following the lines of Blaschko. Pediatr Dermatol 1996;13:219-221.

10 Miteva LG, Dourmishev AL, Schwartz RA: Inflammatory linear verrucous epidermal nevus. Cutis 2001;68:327-330.

11 Ginarte M, Fernandez-Redondo V, Toribio J: Unilateral psoriasis: a case individualized by means of involucrin. Cutis 2000;65:167-170.

12 Happle R: New aspects of cutaneous mosaicism. J Dermatol 2002;29:681-692. 